\title{
Izet Šabotić, ČIFČIJSKI ODNOSI I PROMJENA VLASNIŠTVA NAD ZEMLJOM U BOSNI I HERCEGOVINI (1878-1918), Centar za istraživanje moderne i savremene historije Tuzla, Tuzla 2019, 320 str.
}

Agrarni odnosi i socijalno pitanje uopšte dugo su bili predmet istraživanja među historičarima u Bosni i Hercegovini i okruženju. Posebno veliku pažnju ovom problemu poklanjala je srpska historiografija, ističući potrebu oslobođenja seljaka pravoslavaca u osmanskom i austrougarskom periodu bosanskohercegovačke

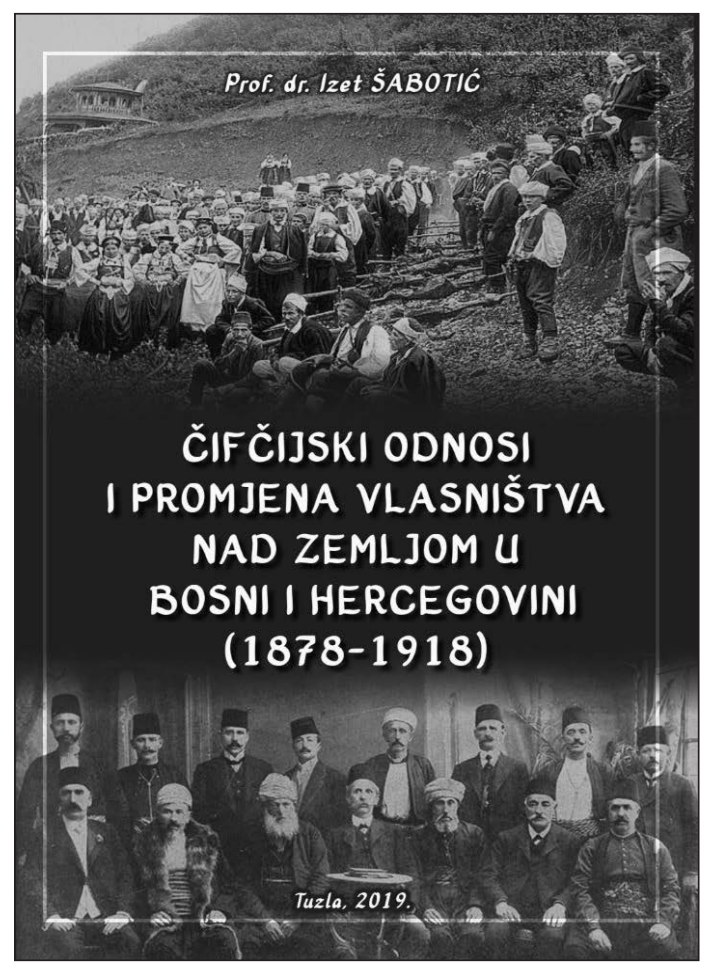
historije. Iako je napisan značajan broj radova, sa sigurnošću se može reći da na socijalno pitanje u historiji i historiografiji nije stavljena tačka, te da ima prostora za nova istraživanja.

Jedno takvo istraživanje obavio je prof. dr. Izet Šabotić sa Odsjeka za historiju Filozofskog fakulteta Univerziteta u Tuzli, a rezultati istog predstavljeni su knjigom Čifčijski odnosi i promjena vlasništva nad zemljom u Bosni $i$ Hercegovini (1878-1918). Knjiga je objavljena u izdanju Centra za istraživanje moderne i savremene historije Tuzla 2019. godine, uz recenziju prof. dr. Senaida Hadžića i prof. dr. Adnana Velagića. Ova knjiga, napisana na 320 strana, predstavlja naučno djelo u punom smislu te riječi, budući da je autor koristio obilatu neobjavljenu arhivsku građu iz fondova Arhiva Bosne i Hercegovine u Sarajevu, Arhiva Tuzlanskog kantona u Tuzli, Akademije nauka i umjetnosti Bosne i Hercegovine u Sarajevu, Državnog arhiva Crne Gore u Podgorici i Državnog arhiva Makedonije u Skoplju. Pored toga, korišteni su i objavljeni dokumenti, štampa iz Bosne i Hercegovine, Srbije, Crne Gore, Austrije, Mađarske i Češke, te veći broj knjiga i članaka. 
Knjiga se sastoji od pet hronološki poredanih poglavlja. Prvo poglavlje nosi naziv Velika istočna kriza i okupacija Bosne i Hercegovine, u kojem je autor dao kraći osvrt na okolnosti dolaska austrougarske okupacione uprave u Bosanski vilajet, odnosno Bosnu i Hercegovinu kako je službeno nazivana od 1878. godine. U fokus pažnje autor postavlja agrarno pitanje kao socijalnu podlogu Bosanskohercegovačkog ustanka, nacionalno pitanje kao političku podlogu istog, te ulogu velikih europskih sila u rješavanju cijelog spleta događaja nama poznatih kao Velika istočna kriza. Autor je sa pravom kao prvo poglavlje ove knjige odredio upravo Veliku istočnu krizu, jer je ona u konačnici dovela do austrougarske okupacije Bosne i Hercegovine. Pravo da okupira Bosnu i Hercegovinu, Austro-Ugarska je dobila na Berlinskom kongresu, a kao izgovor je iskorišteno upravo socijalno pitanje, odnosno nemiri i nestabilnosti u Bosni i Hercegovini temeljeni na odnosima između zemljoposjednika i čifčija. Dakle, govoriti o socijalnim problemima u Bosni i Hercegovini u austrougarskom periodu bez osvrta na kraj osmanske vladavine ne bi imalo previše smisla.

Naredna tri poglavlja govore o agrarnim prilikama u Bosni i Hercegovini pod austro-ugarskom upravom, a podijeljena su hronološki prema važnim događajima. Tako prvo od tih poglavlja govori o agrarnim odnosima od okupacije do novog ustanka u Hercegovini (1878-1882). Autor je u ovom poglavlju osvijetlio stanje u agraru koje je zatekla austrougarska okupacija, zatim odnose zemljoposjednika i čifčija, te odnos novih vlasti u Bosni i Hercegovini prema agrarnom pitanju i njegovoj složenoj problematici. Također, autor je objasnio važnost Hercegovačkog ustanka iz 1882. i njegov značaj za daljnji razvoj agrarnih odnosa, ali i ukupnih političkih prilika ne samo u Bosni i Hercegovini, nego i u vrhovima Monarhije. On je ukazao na zanimljiv fenomen vezan za Hercegovački ustanak, kada su muslimani i pravoslavci privremeno potisnuli u stranu svoje međusobne socijalne probleme i zajednički nastupili protiv austrougarskih vlasti.

U sljedećem poglavlju autor je obradio agrarne prilike u peridu između gušenja Hercegovačkog ustanka i konstituisanja Sabora Bosne i Hercegovine (18831910). Autor je ovdje rasvijetlio nekoliko važnih momenata u socijalnoj historiji Bosne i Hercegovine ovog perioda, kao što su uprava Benjamina Kallaya i njen značaj za razvoj agrarnih odnosa u Bosni i Hercegovini, zatim faza političke saradnje muslimana i pravoslavaca (borba za vjersko-školsku autonomiju) i njen odraz na agrarne odnose, zatim odlazak Benjamina Kallaya i uvođenje desetinskog paušala, te aneksija Bosne i Hercegovine i njena refleksija na agrarne odnose u zemlji. Posebno zanimljiv fenomen je muslimansko-pravoslavna saradnja u borbi za vjersko-školsku autonomiju i mjesto agrarnih odnosa $u$ širem kontekstu tog vremena. U ovom slučaju je autor još jednom pokazao, slično kao u Hercegovačkom ustanku, da su neriješeni agrarni problemi na relaciji muslimani - pravoslavci još jednom potisnuti u drugi plan zbog političkih interesa i međusobne saradnje sa zajedničkim ciljem. Drugim riječima, autor je utvrdio da iako je agrarno pitanje bilo pitanje svih pitanja u Bosni i Hercegovini tog vremena, ono je padalo u drugi plan kada god je postojala potreba za političkom saradnjom između dvije najbrojnije vjersko-etničke grupe u zemlji. Iz tog 
razloga se može reći da su obje zainteresovane strane kalkulisale sa ovim pitanjem ili čak da nisu bile u cjelosti dosljedne u odbrani socijalnih interesa one strane koju predstavljaju. To svakako nije značilo da su socijalni problemi bili otklonjeni, nego da su samo bili privremeno zamrznuti i da su ostali klica iz koje je mogao, i u konačnici iz koje je proizašao novi sukob između muslimana i pravoslavaca čim je raskinut njihov politički savez. Također, u ovom poglavlju autor je na temelju arhivske građe donio precizne i neizmjerno vrijedne podatke o broju otkupljenih čifčija i novčanoj vrijednosti njihovog otkupa, zatim o udjelu interesanata u osiguravanju novčanih sredstava za otkup čifčija, o socijalnoj i vjersko-etničkoj strukturi svih društvenih kategorija koje su bile vezane za proces otkupa čifčija, te o veličinama zemljišnih posjeda koji su otkupljeni.

Sa konstituisanjem Bosanskohercegovačkog sabora započinje sljedeće poglavlje ove knjige i obuhvata period do kraja Prvog svjetskog rata (1910-1918). U ovom dijelu autor je pažnju posvetio problematici agrarnog pitanja, kao pitanja svih pitanja, na saborskim zasjedanjima i njihovom mjestu u ukupnim društvenopolitičkim okolnostima i odnosima između sada već tri zainteresovane strane. Autor je, naime, ukazao na ulogu agrarnog pitanja u promjenama društveno-političkih odnosa unutar Bosne i Hercegovine i uključivanju katoličkog elementa kao tega koji je donio prevagu u muslimansko-pravoslavnom sukobu. Rezultat toga bilo je pripremanje i usvajanje Zakona o fakultativnom otkupu kmetskih selišta kao konačnog poteza austrougarskih vlasti u cilju rješavanja agrarnog pitanja u Bosni i Hercegovini. Značaj ovog zakona autor je istakao donošenjem velikog broja konkretnih i preciznih podataka u otkupu čifčija prema Zakonu, kao i porijeklu novčanih sredstava upotrijebljenih za otkup. Najveći broj tih podataka temelje se na neobjavljenoj arhivskoj građi, što predstavlja nemjerljiv doprinos ove knjige u boljem i potpunijem razumijevanju problematike agrarnih odnosa u Bosni i Hercegovini. Dalje je autor, prateći hronologiju događaja, ukazao na značaj Balkanskih ratova za razvoj agrarnih odnosa, ali i uopšte međusobnih odnosa muslimana i pravoslavaca, ističući kako su ti odnosi postali zategnutiji i skoro neprijateljski zbog različitih simpatija prema zaraćenim stranama u Balkanskim ratovima. To se odrazilo na proces otkupa čifčija, a vidjelo se prema značajno smanjenom broju otkupljenih čifčija i njihovih selišta. Doduše, veliku ulogu u tome imala je i jednostavna činjenica da je ubrzo nakon Drugog balkanskog rata počeo Prvi svjetski rat, tako da je proces otkupa pao u drugi plan. Tome je posebno doprinijela odluka o suspenziji Bosanskohercegovačkog sabora, čime je zatvorena glavna pozornica na kojoj su se politički predstavnici interesnih strana raspravljali i zalagali za interese svoje strane. Autor je na kraju također donio niz vrijednih podataka o kreditnoj politici u procesu otkupa čifčija, tj. izvorima iz kojih je novac dolazio i kamatnim stopama koje su bile na snazi.

Na temelju svega predstavljenog, autor je na kraju donio vlastiti zaključak o istraživačkom pitanju koje je postavio i po svemu sudeći, uspješno odgovorio. Kao glavne zaključke istakao je najprije složenost agrarnih odnosa u Bosni i 
Hercegovini i ispravnu spoznaju austrougarskih vlasti o drugim elementima koji se prožimaju kroz agrarne odnose. To se prije svega odnosi na činjenicu da bi svako radikalno rješavanja agrarnog pitanja dovelo do ozbiljnog poremaćaja u vjerskoetničkim odnosima unutar Bosne i Hercegovine i to na štetu zemljoposjednika koji su većinom bili muslimani, ali i na štetu austrougarskih vlasti koje su se na iste te zemljoposjednike oslanjale $u$ vođenju svoje politike $u$ okupiranim pokrajinama. Iz tih razloga, autor je istakao da su austrougarske vlasti vodile veoma opreznu socijalnu politiku izbjegavajući donošenje bilo kakvih radikalnih rješenja. Još jedan važan zaključak koji je autor istakao jeste konstantno ekonomsko slabljenje muslimanskog elementa kao posljedice rješavanja agrarnih odnosa. Primjetna je i doza kritike prema muslimanskim zemljoposjednicima koji su dobijali novac na štetu izgubljenih zemljišnih posjeda, a nisu ga uložili u trgovački ili industrijski obrt i time izbjegli ekonomsko propadanje. Na taj način, zaključio je autor, ukupna ekonomska moć muslimanskog elementa u Bosni i Hercegovini je značajno oslabila, što je u vremenu i okolnostima koje su nadolazile bilo pogubno za njih same. Zasnivajući svoju tvrdnju na konkretnim podacima, temeljenim na arhivskoj građi, autor je donio još jedan važan, možda i najvažniji zaključak - proces otkupa čifčija izmijenio je vjersko-etnički odnos u vlasničkoj strukturi, jer je velika većina otkupljenih čifčija bila pravoslavne vjere, manji dio katoličke, a manje od $1 \%$ muslimanske. Time je on ujedno dokazao i naslov knjige, odnosno ono što iz njega proizlazi - da je u austrougarskom periodu došlo do značajne promjene u vlasničkoj strukturi u pogledu vjersko-etničke pripadnosti zemljoposjednika.

Na kraju se može istaći da je autor uspješno odgovorio na istraživačko pitanje dokazujući svoje tvrdnje konkretnim i preciznim podacima temeljenim na neobjavljenoj arhivskoj građi. Ovom knjigom on je dao značajan doprinos u rasvjetljavanju socijalne historije Bosne i Hercegovine, ali i boljem i potpunijem razumijevanju ukupnih društveno-političkih i međunacionalnih odnosa u ovoj zemlji. Knjiga je pisana jednostavnim jezikom i stilom koji je razumljiv ne samo stručnoj i naučnoj, nego i široj čitalačkoj publici. Ona zaslužuje pažnju i poštovanje, te iskreno preporučujem svima onima koji su u mogućnosti da je pročitaju. 